\title{
Pengaruh Implementasi Model Problem Based Learning (PBL) terhadap Kemampuan Berfikir Kritis IPA Siswa SMPN 1 Pakusari
}

\author{
Rizki Intan Rahmawati \\ Program Studi Pendidikan IPA, Fakultas Keguruan dan Ilmu Pendidikan, Universitas Jember, Indonesia. \\ e-mail: rizkiintan81@gmail.com
}

\begin{abstract}
The purpose of the research study is to analyze and find out what problems occur with respect to understanding and the ability to think critically of junior high school students against science subject with the application of the PBL model to better student activity. The method used is the collection of accurate information then analyzed and pretest-postest and fully understood and obtained a conclusion. Based on this preliminary study, it can be concluded that the application of the PBL model can have a positive influence on students thinking ability, which ultimately students can have a high curiosity about the phenomena that exist in the surrounding environment and also students are able to develop and develop the knowledge they already have. then with new knowledge added to the amplifier.
\end{abstract}

Keyword: Problems Based Learning (PBL); Critical Thinking Ability; Environment.

\section{PENDAHULUAN}

Pendidikan adalah suatu pembentukan karakter seseorang guna untuk mencapai tujuan dari bangsa Indonesia dan sesuai dengan yang sudah tertera pada UUD 1945 bahwa pendidikan penting adanya untuk mencapai tujuan dari negara yaitu membentuk karakter yang cerdas dan bermanfaat dalam memajukan bangsa Indonesia, dan mencerdaskan kehidupan bangsa, serta menjadikan pribadi manusia yang bertaqwa kepada Tuhan YME, memiliki akhlak yang mulia, sehat jasmani dan rohani, serta berilmu. Oleh karena itu proses dari suatu pendidikan tidaklah lepas dari suatu pembentukan moral. Karena proses pembelajaran tidak cukup jika hanya mengedepankan perubahan dari sikap dan pengetahuan (knowledge) (Puspitorini, 2014:413-414).

IPA merupakan ilmu yang mempelajari tentang gejala-gejala alam, proses ailmiah yang dapat memberikan perubahan menjadi sikap ilmiah yang merupakan suatu produk dari mata pelajaran IPA yang terdiri dari 3 pokok yaitu konsep, prinsip, dan yang terakhir adalah teori (Oktaviana, 2018:47).

Problem Based Learning (PBL) adalah suatu model pembelajaran yang dapat memberikan macam-macam kondisi dimana suatu permasalahan nyata tersebut dapat terselesaikan dengan penyelidikan yang nyata. Dimana pembelajaran tersebut ialah suatu interaksi yang dapat memberikan perubahan tingkah laku dan sikap dari seseorang. Sehingga dalam pembelajaran yang berbasis PBL disini akan dapat membantu peserta didik agar mereka dapat mengembangkan keterampilan berfikirnya secara kritis dan dapat mengembangkan kemampuan penyelesaian terhadap masalah yang konkret. Tujuan dari penerapan model ini diharapkan agar peserta didik dapat aktif dan berprestasi melalui bagaimana cara mengembangkan konsep dan bagaimana membangun interaksi antara peserta didik yang satu dengan peserta didik lainnya guna menilai apa yang mereka ketahui, mengidentifikasinya, dan kemudian menyimpulkan berdasarkan sumber-sumber akurat yang mereka peroleh (Riyanto, 2009 : 288).

Adapun ciri dari model pembelajaran PBL ini terletak pada proses pembelajaran yang artinya peserta didik tidaklah hanya mendengarkan ceramah dan menghafalkan materi dari pendidik, tetapi peserta didik dituntut untuk berfikir, dan ikut berkontribusi dalam pembelajaran tersebut, bagaimana peserta didik dapat menganalisis dan kemudian menyimpulkan suatu hipotesis. Menurut Arends (2008: 42) ada beberapa karakteristik dari model 
pembelajaran berbasis masalah diantaranya adalah sebagai berikut :

1. Bertanya. Proses pembelajaran berdasarkan masalah ini menyangkutkan permasalahan di lingkungan sekitar kemudian memberikan pertanyaan atas masalah tersebut dan kemudian akan muncul baagaimana solusi yang tepat untuk mengatasi masalah pada kehidupan nyata tersebut.

2. Penyelidikan autentik. Di dalam proses pembelajaran berbasis masalah pastinya terkait dengan ikatan tertentu baik mata pelajaran IPA, matematika, ataupun lainnya. Namun peserta didik diharuskan untuk bisa menemukan masalah nyata dengan solusi yang nyata, mengumpulkan sumber informasi, menganilis hasil informasi, kemudian menarik kesimpulan.

3. Output. Dalam pembelajaran ini peserta didik dituntut untuk menghasilkan suatu karya atau hasil dari pemecahan masalah yang kemudian dapat dipublikasikan dalam bentuk nyata.

4. Bekerja sama. Diharapkan peserta didik mampu bekerja sama dengan peserta didik yang lain untuk dapat menyelesaikan dan mencari solusi dari masalah yang didapatkan. Saling memberikan motivasi satu sama lain guna mempererat hubungan serta untuk meningkatkan pengembangan sosial peserta didik (Trianto: 2010:97).

Kemampuan siswa untuk critical thinking ability (berfikir kritis) dapat dikembangkan dengan penerapan pendekatan model Problem Based Learning (PBL) dimana pendekatan ini merupakan suatu pendekatan dalam proses pembelajaran yang menitik beratkan pada permasalahan sehari-hari yang ada pada keseharian siswa yang kemudian akan dikaitkan dengan proses pembelajaran. Sehingga siswa-siswa tersebut dapat merasakan dan dapat benar-benar memahami antara teori dengan praktik yang dilakukan langsung oleh siswa tanpa mereka sadari. Kemudian siswa dapat berfikir secara terbuka mengenai segala permasalahan yang ada dan secara otomatis siswa akan terlibat aktif dalam proses pencarian solusi dari masalah tersebut di dalam konteks pembelajaran (Jacobsen, 2009: 172). Menurut Suyanto (2011: 97) berfikir kritis adalah suatu upaya dimana proses peningkatan secara sistematis kognitif siswa dengan pemikiran yang harus lebih peka untuk merumuskan, menganalisis, dan mengevaluasi prinsip dan pendapat dari siswa tersebut. Pendapat lain juga dikemukakan oleh Fieldman (2010: 21) yang menyatakan bahwa seorang siswa yang memiliki kemampuan berfikir kritis akan mampu mengembangkan dan mencari solusi/jawaban dengan sendirinya, cerdas, dapat memperbaiki kesalahannya. Sehingga kemampuan tersebut dapat membuka pemikiran seorang siswa untuk berfikir secara rasional dan tidak mudah percaya akan hal-hal yang belum tentu jelas kebenarannya.

\section{METODE PENELITIAN}

Metode yang digunakan adalah teknik pengumpulan data atau sumber-sumber yang berdasar pada sumber yang akurat dan terpercaya, melakukan survei ke SMP Negeri 1 Pakusari. Sesuai dengan studi literatur ini lalu dianalisis menggunakan cara deskriptif kemudian dilakukan eksperimen dengan pretest-postest lalu penarikan kesimpulan terhadap model PBL guna meningkatkan kemampuan berfikir kritis siswa SMP Negeri 1 Pakusari.

Instrumen yang digunakan dalam penelitian ini berupa tes pilihan ganda yang beralasan sedangkan pada pendidik diberikan tes pilihan ganda yang beralasan (Ya, Tidak), (Setuju, Sangat Setuju, Raguragu, Tidak setuju, Sangat Tidak Setuju) yang diberikan kepada peserta didik. Dengan populasi penelitian didasarkan pada kelas VIII E sebagai eksperimen dan kelas VIII B sebagai kelas kontrol. Sebelum dilakukan penelitian, dilakukan uji coba tes untuk mengetahui validitas, reliabel, tingkat kesulitan tes, dan daya pembeda tes.

Teknik analisis data dilakukan dengan analisis deskriptif dengan membuka masalah yang ada pada pendidik dan peserta didik baik dari metode yang digunakan pendidik lalu respon peserta didik. Uji hipotesis dilakukan dengaan uji $t$ menggunakan nilai mean atau rata-rata 
antara kedua kelas eksperimen tersebut. Kemudian data dianalisis dengan menggunakan aplikasi SPSS 20 for windows.

\section{HASIL DAN PEMBAHASAN}

Berdasarkan hasil analisis deskriptif mengenai model PBL secara umum upaya peningkatan kemampuan berfikir kritis pada setiap permasalahan digunakan metode yang tepat agar setiap peserta didik mampu memahami dan membantu peserta didik agar mengasah kemampuannya berfikir secara rasional tetapi dengan situasi yang kondusif dan menyenangkan.
Pada dasarnya materi yang disampaikan oleh pendidik akan mudah diserap oleh siswa apabila siswa mempunyai keaktifan dan rasa ingin tahu yang sangat tinggi dengan kemudian didukung oleh pengaplikasian metode pembelajaran yang tepat dan disukai oleh siswa. Namun kebanyakan pendidik masih menggunakan metode ceramah dimana metode tersebut terkesan membuat peserta didik menjadi cepat bosan dan mengantuk.

Berikut merupakan hasil rekapitulasi dari angket yang sudah diberikan kepada beberapa pendidik di SMP Negeri 1 Pakusari.

Tabel 1. Rekapitulasi Hasil Angket Pendidik

\begin{tabular}{|c|c|c|c|}
\hline No. & Pertanyaan & Ya & Tidak \\
\hline 1. & $\begin{array}{l}\text { Apakah bapak/ibu mengetahui tentang critical thinking } \\
\text { ability (kemampuan berfikir kritis)? }\end{array}$ & 4 & 1 \\
\hline 2. & $\begin{array}{l}\text { Apakah bapak/ibu pernah merancangkan strategi } \\
\text { pembelajaran khusus untuk meningkatkan kemampuan } \\
\text { berfikir kritis siswa? }\end{array}$ & 5 & \\
\hline 3. & $\begin{array}{l}\text { Apakah bapak/ibu pernah menerapkan metode } \\
\text { pembelajaran lain selain dari metode ceramah? }\end{array}$ & 5 & \\
\hline 4. & $\begin{array}{l}\text { Pernahkah bapak/ibu menggunakan media (alat peraga) } \\
\text { untuk pembelajaran? }\end{array}$ & 5 & \\
\hline 5. & $\begin{array}{l}\text { Apakah bapak/ibu perlu mengubah strategi pembelaran } \\
\text { yang sudah bapak/ibu terapkan sebelumnya setelah } \\
\text { adanya peralatan elektronik yang canggih di era ini ? }\end{array}$ & 5 & \\
\hline
\end{tabular}

Berdasarkan data diatas dapat diketahui bahwa terdapat 1 orang guru yang tidak mengerti tentang kemampuan berfikir kritis siswa. Dalam Lidinillah (2013: 4) bahwa seorang guru berperan sebagai fasilitator sangat penting sekali dikarenakan nantinya akan berpengaruh terhadap hasil belajar siswanya. Dalam hal ini peran guru sebagai fasilitator adalah mengamati aktivitas belajar siswa, memfasilitasi siswa dengan sarana dan prasarana, dan memberikan stimulus kepada siswa dan guru harus mengetahui dengan baik tahapan kerja siswa dan bagaimana pola pikir siswa. Namun masih terdapat guru yang belum mengetahui apa itu kemampuan berfikir kritis. Kemudian mengenai seorang guru haruslah membuat rancangan strategi pembelajaran khusus untuk siswanya guna meningkatkan kemampuan berfikir kritis siswa. Nurdyansyah (2017) menjelaskan bahwa tujuan dari pembelajaran ini untuk tercapainya pembelajaran yang efektif dan efisien, dengan kata lain belajar tersebut dilakukan yang merupakan bentuk dari suatu proses untuk melakukan aktivitas demi mendapatkan sebuah pengalaman yang baru. Sesuai pendapat Zainuddin (2018: 82) yang menyatakan bahwa guru di dalam proses pembelajaran diharapkan tidak monoton dalam menyajikan materi kepada peserta didiknya, hal tersebut dikarenakan agar peserta didik dapat termotivasi dalam proses belajar. Seorang guru dapat memilih dan menerapkan model pembelajaran beserta dengan media yang dibutuhkan yang berhubungan dengan pembelajaran IPA agar terciptanya situasi belajar yang kondusif dan 
menyenangkan. Sesuai dengan yang disebutkan Widodo (2018: 220-222) yang menyatakan bahwa seorang guru merupakan bagian terpenting dalam proses pembelajaran dan mengharuskan sekolah untuk mengoptimalkan inovasi pada guru. Dalam pengoptimalisasian tersebut pihak sekolah harus menjadi organisasi dalam pembelajaran yang dapat memungkinkan agar guru lebih terbebas untuk melakukan inovasi-inovasinya di sekolah, baik secara eksplorasi ataupun generatif, investigasi informatif, memobilisasi sumber daya, maupun pengaplikasian. Sehingga dalam ruang lingkup tersebut sekolah haruslah memiliki komitmen yang kuat untuk mengembangkan pelayanan pendidikan agar sekolah tersebut memiliki keunggulan dibandingkan dengan sekolah lainnya. Sekolah merupakan tempat terjadinya suatu proses pembelajaran, yang dimana sekolah haruslah memiliki revitalisasi dalam pembelajaran diantaranya mendorong keterbukaan dan eksperimentasi pada guruguru melalui penerimaan dan penerapan terhadap inovasi-inovasi terbaru dan berkelanjutan, kemandirian individu untuk memecahkan masalah, pembelajaran yang berkelanjutan dengan bercermin pada masa lalu. Kemudian ada motovasi dan memfasilitasi transfer serta integrase pengetahuan pada guru dalam pembangunan dan mewujudkan kerja sama tim dalam pembelajaran, melakukan pemecahan masalah secara kreatif dan kolektif. Karena inovasi seorang pendidik sangatlah dibutuhkan sehingga sekolah haruslah membantu untuk mewujudkan inovasi pendidik melalui revitalisasi tersebut.

Rofiah (2013:17) menyebutkan bahwa kemampuan berfikir tingkat tinggi seseorang diartikan proses bagaimana seseorang dapat berfikir secara menyeluruh guna mendapatkan tantangan yang baru baginya. Dimana seorang siswa diharuskan untuk mengeksplor pengetahuanpengetahuannya sendiri dengan kreatif.

Pada model PBL siswa ditempatkan sebagai self-directed learned sehingga siswa dapat mempunyai peranan lebih besar daripada pendidik dalam hal membangun pengetahuan pada siswanya. Pembelajaran berbasis masalah tidaklah hanya memberikan masalah kemudian menyelesaikannya tetapi juga membangun dan menciptakan pengetahuan sendiri melalui interaksi antar peserta didik yang satu dengan lainnya (bekerja sama) ( Happy, 2014: 55).

Siswa lebih terdorong untuk mengaplikasikan informasi yang sudah diketahuinya dan mendapatkan informasi tambahan yang dibutuhkan. Upaya peningkatan kemampuan berfikir kritis ini lebih efektif digunakan apabila dilihat dari kemampuan berfikir kreatif dan inovatif. Pengetahuan yang didapatkan siswa dari berbagai masalah konkret tersebut memeiliki beberapa kebenaran diantaranya bahwa belajar yang melalui proses penemuan penting, dikarenakan menurut Karim (2011:24) bahwa ilmu-ilmu tersebut dikembangkan berdasarkan kemampuan berfikir kritis.

Untuk meningkatkan kerja otak peserta didik, diperlukan adanya pelatihan guru mengenai metode yang digunakan pada saat pembelajaran. Sehingga munculah rasa ingin tahu siswa yang menghasilkan output sering bertanya jawab. Tahap Tanya jawab peserta didik disini dapat digunakan guru untuk penilaian terhadap seberapa besar pemahaman peserta didik mengenai materi, dapat memungkinkan peserta didik untuk mempraktikkan langsung dan menguasai topik yang diajarkan sebelum berganti ke topik pembelajaran yang selanjutnya, dapat memungkinkan peserta didik untuk mengungkapkan pemikiran dan pemahaman peserta didik mengenai konsep pembelajaran yang sudah diajarkan. Output yang selanjutnya adalah hasil belajar yang merupakan perkembangan tingkat pemahaman baik dari segi kognitif, afektif, dan psikomotor. Jika ditinjau dari sisi pendidik, hasil belajar adalah penyelesaian bahan yang sudah diajarkan setelah pendidik menerapkan model pembelajaran dengan harapan peserta didik dapat menunjukkan peningkatan dari pemahaman topik yang sudah diajarkan sesuai dengan ketentuan KKM pada suatu sekolah (Zainudin, 2018:84-85).

Dengan adanya model pembelajaran Problem Based Learning (PBL) maka siswa akan menjadi mandiri dan terbiasa dengan 
rasa keingin tahu-an mereka yang tinggi dan memunculkan sikap ataupun pemikiran yang kritis terhadap lingkungan sekitar secara nyata.

Tabel 2. Deskripsi Nilai Pretest Yang Diberikan Dengan Kemampuan Berfikir Kritis Peserta Didik Dengan Model PBL Dengan Kelas Kontrol.

\begin{tabular}{lll}
\hline Keterangan & PBL & Kontrol \\
\hline Nilai Min & 45.00 & 45.00 \\
\hline Nilai Max & 89.00 & 80.00 \\
\hline Mean & 67.30 & 63.15 \\
\hline Standar Deviasi & 13.13 & 11.95 \\
\hline $\begin{array}{l}\text { Kolgomoronov-Smirnov } \\
\text { Z }\end{array}$ & 0.171 & 0.139 \\
\hline Signifikansi & 0.127 & \\
\hline
\end{tabular}

Hasil kemampuan berfikir kritis peserta didik setelah diadakan postest sebagai berikut:

Tabel 3. Deskripsi Nilai Postest Yang Diberikan Dengan Kemampuan Berfikir Kritis Peserta Didik Dengan Model PBL dan Kontrol.

\begin{tabular}{lll}
\hline Keterangan & PBL & Kontrol \\
\hline Nilai Min & 50.00 & 54.00 \\
\hline Nilai Max & 92.00 & 80.00 \\
\hline Mean & 75.85 & 68.25 \\
\hline Standar Deviasi & 11.926 & 9.458 \\
\hline $\begin{array}{l}\text { Kolgomoronov-smirnov } \\
\text { Z }\end{array}$ & 0.152 & 0.123 \\
\hline Signifikansi & & \\
\hline
\end{tabular}

Kemudian digunakan uji homogenitas data menggunakan uji Lavene's hasil dari pembelajaran peserta didik menampilkan variasi data antara dua kelompok sampel dalam populasi yaitu homogen dengan nilai signifikan uji Lavene $>0.05(\operatorname{sig}=0.760)$.

Selanjutnya hasil dari analisis uji Independent Sample t-tes menampilkan bahwa terdapat peningkatan yang cukup signifikan terhadap kemampuan berfikir kritis peserta didik antara sebelum diterapkannya PBL dengan sesudah diterapkannya PBL (nilai signifikan $=0.027$ ). Sehingga diperoleh berdasarkan hasil hipotesa sebelumnya jika nilai sig(2-tailed) < 0.05 maka Ho diterima dan Ha ditolak yang menyatakan bahwa terjadi peningkatan signifikan terhadap kemampuan berfikir kritis pada peserta didik yang diterapkan dengan model pembelajaran PBL.

\section{SIMPULAN}

Untuk menanggulangi permasalaahan terhadap kemampuan berfikir kritis peserta didik maka digunakanlah model pembelajaran Problems based learning $(P B L)$ dimana di dalam metode ini peserta didik dituntut untuk berfikir secara terbuka dan rasional terhadap fenomena-fenomena yang ada di sekitarnya sehingga siswa akan dapat terdorong untuk selalu ingin tahu terhadap permasalahan yang ada di lingkungan sekitar.

Namun pada SMPN 1 Pakusari terkadang masih menggunakan metode ceramah meskipun sedikit demi sedikit mulai menerapkan pembaruan model pembelajaran yang memungkinkan diterapkan pada sekolah tersebut.

Namun pada kenyataannya setelah dilakukan penelitian bahwa penerapan model pembelajaran PBL ini sangatlah berpengaruh terhadap kemampuan berfikir kritis peserta didik terutama pada mata pelajaran IPA yang dimana peserta didik dapat berksplorasi secara bebas dan lebih leluasa guna mengembangkan kemampuan berfikir kritis. 


\section{SARAN DAN/ATAU UCAPAN TERIMA KASIH}

Setelah adanya penelitian ini diharapkan para pendidik dapat menerapkan model-model pembelajaran yang baru agar dapat melatih kekreatifan peserta didik dan juga dapat melatih kemampuan peserta didik dalam mengeksplorasi pengetahuannya secara mandiri.

Dan diucapkan terima kasih yang sebesar-besarnya kepada guru dan siswa SMP Negeri 1 Pakusari yang sudah mau berkontribusi dalam penelitian ini.

\section{DAFTAR PUSTAKA}

Fieldman, D. (2010). Berfikir Kritis Strategi untuk Pengambilan Keputusan. Jakarta: PT Indeks

Happy, Nurina. dkk. (2014). Keefektifan PBL Ditinjau Dari Kemampuan Berfikir Kritis dan Kreatif Matematis, Serta Self-Esteem Siswa SMP. Jurnal Riset Pendidikan Matematika. Volume 1 Nomor 1 Mei 2014

Jacobsen. (2009). Methods For Teaching (Metode-Metode Pengajaran). Yogyakarta: Pustaka Belajar

Karim, Asrul. (2011). Penerapan Metode Penemuan Dalam Pembelajaran Matematika Untuk Meningkatkan Pemahaman Konsep Dan Kemampuan Berfikir Kritis Siswa Sekolah Dasar. Jurnal Edisi Khusus. No 1 Agustus 2011

Lidnillah, D. A. M. (2013). Pembelajaran Berbasis Masalah (PBL). Jurnal pendidikan inovatif. UPI education.

Nurdyansyah,.dkk. (2018). Pengaruh Dari Strategi Pembelajaran Aktif Terhadap Hasil Belajar Pada Madrasah Ibtidaiyah. Universitas Muhammadiyah Malang. Umsida

Oktaviana, Bela., dkk. (2018). Keefektifan Pembelajaran IPA Materi Pesawat Sederhana Menggunakan Model Pair Check Menggunakan Question Card
Pada Siswa Kelas V SDN Sukoharjo 01 Pati. Jurnal Profesi Pendidikan Dasar. Vol. 5 No. 1 Juli 2018 e-ISSN 2603-3530 p-ISSN 2406-8012

Puspitorini, Retno., dkk. (2014). Pemanfaatan Media Komik Dalam Pembelajaran IPA Untuk Meningkatkan Motivasi dan Hasil Belajar Kognitif Dan Afektif. Jurnal Cakrawala Pendidikan. Oktober 2014 No. 3

Riyanto, Yatim. (2009). Paradigma Baru Pembelajaran. Jakarta: Kencana Prenada

Rofiah, Eni., dkk. (2013). Penyusunan Instrumen Tes Kemampuan Berpiir Tingkat Tinggi Fisika Pada Siswa SMP. Jurnal Pendidikan Fisika. Vol 1 No 2

Suyanto, Slamet. (2011). Implementasi Pendidikan Karakter Melalui Pembelajaran Terpadu. Jurnal Cakrawala Pendidikan. No3

Trianto. (2010). Model Pembelajaran Terpadu. Jakarta : Bumi Aksara

Widodo, W. (2018). Peranan Organisasi dalam Mengoptimalkan Inovasi Guru. Jurnal Bimbingan dan Konseling. Volume 1 Nomor 32018 p-ISSN: 2580-2046 e-ISSN: 2580-2054

Zainuddin, Nur Azizah. (2018). Peningkatan Motivasi Belajar IPA melalui Penerapan Model Scramble. Jurnal Islamic elementary School. Volume 1 No 1 halaman 81-90 pISSN; 2356-1483 e-ISSN: 2356-148 